\title{
FACTORS OF PHENOTYPIC AND GENOTYPIC RESISTANCE OF THE MOST PROBLEMATIC INFECTIOUS AGENTS IN INTENSIVE CARE UNIT
}

\author{
Vitebsk State Medical University ', Vitebsk, \\ Minsk Scientific and Practical Center of Surgery, Transplantation and Hematology ${ }^{2}$, Minsk, \\ The Republic of Belarus
}

Цель. Установить факторы фенотипической и генотипической резистентности наиболее проблемных возбудителей инфекции в отделении реанимации и интенсивной терапии.

Материал и методы. Проведено комплексное обследование 99 пациентов отделения реанимации и интенсивной терапии, из мокроты которых выделено 224 клинических изолята. Для изолятов Klebsiella pneumonia выполнена детекция генов карбапенемаз методом полимеразной цепной реакции в режиме реального времени и определены минимальные подавляющие концентрации антибиотиков для микроорганизмов в планктонной форме и форме биопленки методом двукратных серийных разведений.

Результаты. В структуре исследованных изолятов чаще встречались Acinetobacter spp. (32,6\%), Klebsiella pneumonia (33,5\%), Pseudomonas aeruginosa (14,7\%). 91,4\% изолятов Klebsiella рпеитопіае обладали генами резистентности, причем в большинстве случаев - геном резистентности ОХА-48 (80\%). Все исследованные изоляты умеренно или хорошо формировали биопленку, при этом среди изученных микроорганизмов данная способность наиболее выражена у Proteus mirabilis. Все изоляты как в планктонной форме, так и в форме биопленки были чувствительны к тигециклину (100\%), проявив устойчивость к карбапенемам в 94,7\%, к цефалоспоринам - в 100\% случаев. Для 90\% исследованных изолятов минимальная подавляющая концентрация для тигециклина и ципрофлоксацина в составе биопленки не меняется, но возрастает в среднем для моксифлоксацина в 1,3 раза и меропенема в 1,2 раза.

Заключение. Установлены факторы фенотипической и генотипической резистентности наиболее проблемных возбудителей инфекции в отделении реанимации и интенсивной терапии. Установлена взаимосвязь антибиотикорезистентности Klebsiella pneumonia с продукцией карбапенемаз. Большая часть изолятов Klebsiella pneumoniae, резистентных к карбапенемам и цефалоспоринам, имела ассоциации генов: OXA-48 и СТX-M (37,1\%), NDM и СТX-M (2,9\%), NDM и OXA-48 (37,1\%), CTX-M и OXA-48 $(11,4 \%)$. Идентификация генов резистентности, определяющих синтез карбапенемаз и цефалоспориназ, позволяет исключить антибиотики, разрушаемые данными ферментами, из алгоритмов антибактериальной терапии.

Ключевые слова: антибиотикорезистентность, Klebsiella pneuтоniae, Acinetobacter spp., Pseudomonas aеruginosa, формирование биолленок, гены резистентности

Objective. To establish factors of phenotypic and genotypic resistance of the most problematic infectious agents in the intensive care unit.

Methods. A comprehensive examination of 224 clinical isolates from the sputum of 99 patients in the intensive care unit was performed. Carbapenemase genes in Klebsiella pneumonia isolates were detected by realtime polymerase chain reaction and minimum inhibitory concentrations of antibiotics for microorganisms were determined in planktonic form and biofilm form by the method of double serial dilutions.

Results. In the structure of the studied isolates the most common were Acinetobacter spp. (32.6\%), Klebsiella pneumonia (33.5\%), Pseudomonas aeruginosa (14.7\%). 91.4\% of Klebsiella pneumoniae isolates possessed genes of resistance and in most cases - OXA-48 (80\%). All the studied isolates moderately or well formed the biofilm, among the studied microorganisms Proteus mirabilis demonstrated this ability best of all. All isolates both in plankton form and in the form of biofilm were sensitive to tigecycline (100\%) and resistant to carbapenems in $94.7 \%$, to cephalosporins - in $100 \%$ of cases. For $90 \%$ of the studied isolates the minimum inhibitory concentration for tigecycline and ciprofloxacin in the biofilm does not change and increases for moxifloxacin in 1.3 times, for meropenem -1.2 times.

Conclusions. The factors of phenotypic and genotypic resistance of the most problematic infectious agents in the intensive care unit have been established. Most of the carbapenemresistant Klebsiella pneumoniae isolates (88.5\%) had gene associations: OXA-48 and CTX-M (37.1\%), NDM and CTX-M (2.9\%), NDM and OXA-48 (37.1\%), CTX-M and OXA-48 (11.4\%). The identification of resistance genes that determine the synthesis of carbapenemazes and cefalosporinazes eliminates the antibiotics that are destroyed by these enzymes from the algorithms of antibacterial therapy.

Keywords: antibiotic resistance, Klebsiella pneumoniae, Acinetobacter spp., Pseudomonas aeruginosa, biofilm formation, resistance genes 
Novosti Khirurgii. 2019 Mar-Apr; Vol 27 (2): 188-195

Factors of Phenotypic and Genotypic Resistance

of the Most Problematic Infectious Agents in Intensive Care Unit

V.Y. Ziamko, V.K. Okulich, A.M. Dzyadzko

\section{Научная новизна статьи}

Впервые получены данные о высокой устойчивости проблемных возбудителей нозокомиальной микрофлоры в составе биопленки к антибактериальным препаратам: к меропенему, имипенему, ципрофлоксацину в отделении реанимации и интенсивной терапии; установлена взаимосвязь фенотипической антибиотикоустойчивости Klebsiella pneumoniae с продукцией карбапенемаз, которая определяется генами резистентности OXA-48, NDM, CTX-M.

\section{What this paper adds}

The data on antibiotic resistance of problematic representatives of nosocomial microflora in the biofilm composition to meropenem, imipenem, ciprofloxacin in the intensive care unit have been obtained for the first time; the relationship of phenotypic resistance of Klebsiella pneumoniae and carbapenemase producing has been established, which is determined by the resistance genes OXA-48, NDM, CTX-M.

\section{Introduction}

Despite the fact that infections are not always the main cause of mortality for patients in intensive care units (ICU), they are definitely associated with an increase in the length of hospital stay and the cost of treatment. Hospital-acquired infections in the ICU comprise $15-20 \%$ of all infectious processes in the hospital and may further lead to complications in $>40 \%$ of patients in critical condition [1]. The increase in mortality is associated with the presence of laboratory-confirmed infections caused by the group of resistant microorganisms, designated by the American Society for Infectious Diseases, as ESKAPE pathogens. These include vancomycinresistant enterococci, carbapenem-resistant members of the Enterobacteriaceae family, colistin-resistant representatives of Acinetobacter spp., multi-resistant Pseudomonas aeruginosa and MRSA [1].

Inadequate starting antibiotic therapy leads to an increase in hospitalization and mortality [2], additional costs and an increase in resistance [3]. The basis for the administering antimicrobial drugs is the presence of clinical signs of an infectious process or the presence of an established pathogen. In patients with severe bacterial infections, every hour of delayed administration of effective drugs is associated with an increase in mortality of $7.6 \%$ in the first 6 hours [4]. However, when prescribing empirical therapy for severe infections, a dilemma arises between the need for the widest possible coverage of potential pathogens to ensure adequate treatment, on the one hand, and minimization of antibiotic-resistant strains selection, on the other hand. The use of carbapenems as a starting empirical therapy for severe hospital infections during 48 hours before the results of microbiological research led to the formation and selection of multi-resistant strains of bacteria and the ineffectiveness of this group of drugs [5].

The growth of carbapenem-resistant representatives of the family Enterobacteriaceae is also characteristic for the Republic of Belarus. Thus, the number of carbapenems resistant to $K$. pneumonia increased from $11.7 \%$ in 2015 to $78.7 \%$ in 2017 and is currently a serious threat [6]. The number of known carbapenemases, which determine resistance to carbapenems, is constantly increasing, but only four types are most widely used in hospitals in the CIS countries: NDM-type, VIM-type, KPC-type, OXA-48-type. The first two enzymes are metal beta-lactamases, and the last two are serine betalactamases. Associated with the resistance to most $\beta$-lactam drugs, carbapenemases are an important marker of extreme antibiotic resistance of $K$. pneumoniae [7].

Also? one of the reasons for the growth of antibiotic resistance of microorganisms is the possibility of the existence of most of them in the form of communities called biofilms (BF). As part of BF, microorganisms exhibit astonishing resistance to any influences, including antibiotics [8]. The antibiotic sensitivity of bacteria in the composition of biofilms is much lower compared with the sensitivity of isolates of pure cultures, which in turn makes the antibiotic unpromising, based on data obtained in the bacteriological laboratory [9].

Currently, PCR diagnostics is a faster and more promising method of microbiological identification. Based on the study of the genetic material of microorganisms, namely DNA and RNA contained in the biological material obtained from patients, PCR diagnostics allows determining the presence of the pathogen with a minimum amount as soon as possible, which is especially important in the ICU. For example, PCR analysis allows detecting MRSA within a few hours, unlike the traditional bacteriological method, which requires at least 3-5 days to conduct a study, which is extremely important for the rapid appointment of the targeted antibiotic therapy in the ICU [10].

Objective. To establish the factors of phenotypic and genotypic resistance of the most problematic pathogens in the intensive care units. 


\section{Methods}

The study included 99 patients who were being treated at the ICU of ME "Vitebsk Regional Clinical Hospital" during 2016-2018. The structure was dominated by men, comprising 71 people $(71.7 \%)$; women - 28 people $(28.3 \%)$. The average age of men was $56.0 \pm 14.6$, women $55.4 \pm 16.6$ years $(\mathrm{M} \pm \sigma)$. Table 1 presents data on the distribution of patients depending on the nosology.

All patients had single and bilateral polysegmental or lobar pneumonia. $16(16.2 \%)$ patients had an out-of-hospital pneumonia, the rest had hypostatic pneumonia. Of these, 59 (59.6\%) patients with pneumonia were on artificial lung ventilation (ALV). On average, pneumonia developed at 4.6 [1.5-9.9] (Me [LQ-UQ]) day, while $64.1 \%$ of cases were early pneumonias that developed on the 5th day after hospitalization, $35.9 \%$ - late ones. The severity of the patient's condition was assessed according to the SAPS II scale during the first 24 hours after admission to the ICU.

Phenotypic and genotypic features of 224 isolates obtained from the sputum were studied. The sputum was taken on an empty stomach in the morning to sterile tubes, and in patients on mechanical ventilation, by aspiration from the tracheobronchial tree. Microorganisms were identified according to application instruction No. 075-0210 "Microbiological methods for the study of biological material", approved by the Ministry of Health of the Republic of Belarus on March 13, 2010 [11].

Microbial biofilms were studied using previously developed methods [12]. The ability of the obtained isolates to form the biofilm within 2

Table 1

Distribution of patients depending on the nosology

\begin{tabular}{lc}
\hline \multicolumn{1}{c}{ Nosology } & $\begin{array}{c}\text { Number } \\
\text { of patients }(\%)\end{array}$ \\
\hline Traumatic brain injury & $10(10.1 \%)$ \\
Sepsis & $4(4.0 \%)$ \\
Pneumonia & $17(17.2 \%)$ \\
Chronic obstructive lung disease & $3(3.0 \%)$ \\
Acute cerebrovascular accident & $19(19.2 \%)$ \\
Severe concomitant injury & $8(8.1 \%)$ \\
Acute arterial circulatory disorders & $1(1.0 \%)$ \\
Myasthenia & $2(2.0 \%)$ \\
Aneurysm & $1(1.0 \%)$ \\
Acute infectious lung destruction & $5(5.1 \%)$ \\
Pancreatitis & $12(12.1 \%)$ \\
Cholelithiasis & $1(1.0 \%)$ \\
Peritonitis & $5(5.1 \%)$ \\
Soft tissue infection & $8(8.1 \%)$ \\
Brain infection & $2(2.0 \%)$ \\
Acute intestinal obstruction & $1(1.0 \%)$ \\
\hline
\end{tabular}

days was determined, as well as the mass of the formed microbial film with the method using a 96-well polystyrene plate. According to the data obtained on the spectrophotometer, the average optical density of the experimental samples was calculated and the weight of the microbial biofilm, expressed in $\mathrm{mg} / \mathrm{well}$, then using the table the ability of the microorganism to form BF such as low, moderate or high was determined. The determination of the MIC value of antibiotics was carried out by dilution in Muller-Hinton agar [12]. The sensitivity of the isolate to antibiotics was evaluated in accordance with the recommendations of the European Committee for testing antimicrobial resistance [13].

Part of the isolates was determined by real-time PCR method. To determine DNA of Streptococcus spp., Escherichia coli, Enterococcus faecalis, Enterobacter spp., Enterococcus faecium, Klebsiella spp., Proteus spp., Staphylococcus aureus, Serratia spp., Pseudomonas aeruginosa, the reagent kit "Septoskrin" (Russia) was used. To determine Litekh the resistance genes for carbapenems (VIM, NDM, OXA-48, KPC) and cephalosporins (CTX-M), "Fluoropol-RV" reagent kits in the "OneStep" configuration were used. The result was evaluated in the Bio Rad CFX Manager 3.0 program. In case of accidental contamination of the sample, the concentration of the genetic material of the pathogen was minimal and was located at the lower limit of the method sensitivity.

\section{Statistics}

The obtained results were statistically processed using Microsoft Excel 2007, Statistica (Version 10, StatSoft Inc., USA, license No. STA999K347156W). The normal distribution was determined using the Shapiro-Wilk test. In a distribution close to normal, parametric methods of statistical analysis were used; the values of the analyzed parameters in the groups were presented as mean values and standard deviations. For the distribution different from normal, non-parametric methods of statistical analysis were used; the results are presented as a median indicating the lower 25th and upper 75 th quartiles. The reliability of the intergroup figures of the mean values was evaluated by the Mann-Whitney test. When calculating the statistical reliability of the compared values, we assumed a significance level of $p \leq 0.05$. To study the relationship between quantitative variables when the distribution is different from normal, Spearman's rank correlation was used. The significance level of $p<0.05$ meant a significant correlation between the signs. 


\section{Results}

The severity of the patient's condition was assessed according to the SAPS II scale during the first 24 hours after admission to the ICU. The level of neurological status on the Glasgow coma scale owas 13 [8-15] points; systolic blood pressure $123.4 \pm 12.3$ mmHg.; the number of leukocytes was $13.89 \pm 7.6$ $\times 10^{12}$ per liter; HR $-84.3 \pm 15.6$ beats per minute; 59 $(59.6 \%)$ patients were on artificial lung ventilation; sodium indicator was $140.3 \pm 8.7 \mathrm{mmol} / \mathrm{l}$; potassium $4.42 \pm 1.1 \mathrm{mmol} / \mathrm{l}$; temperature $-37.6 \pm 0.9^{\circ} \mathrm{C}$; diuresis volume was $115.01 \pm 48.1 \mathrm{ml} /$ hour; $\mathrm{HCO} 3$ indicator was $22.6 \pm 1.9 \mathrm{mmol} / \mathrm{l}$, the level of urea was $15.4 \pm 14.2 \mathrm{mmol} / \mathrm{l} ; 1(1.0 \%)$ of the patients was diagnosed with cancer. 55 (55.6\%) patients died, while the probability of an unfavorable prognosis on the SAPS II scale was determined only in 23 $(41.8 \%)$ of them.

75 isolates $(33.5 \%)$ of $K$. pneumoniae was obtained, 73 isolates (32.6\%) of Acinetobacter spp., 33 isolates $(14.7 \%)$ of $P$. aeruginosa, 22 isolates $(9.8 \%)$ of $S$. aureus, 5 isolates (2.2\%) of Enterococcus faecium, 5 isolates (2.2\%) of P. mirabilis, 3 isolates (1.3\%) of $E$. coli, 2 isolates $(0.9 \%)$ of $S$. epidermidis, and 1 isolate $(0,4 \%)$ of $S$. haemolyticus. When DNA was isolated from biological material by PCR, in all cases associations of microorganisms were isolated, despite the fact that in 3 cases the absence of microflora growth was determined by the bacteriological method. The results are presented in tables 2 and 3.

When studying the ability to form a biofilm, it was found out that $10(45)$ isolates of $S$. aureus formed a biofilm intensively; $12(54.5 \%)$ isolates formed a biofilm moderately. $58(76.3 \%)$ of $K$. pneumoniae isolates intensively formed a biofilm and $17(32.7 \%)$ had a moderate ability to form a biofilm. Most isolates of Acinetobacter spp. -47 (63.5\%) also formed a biofilm very well; $26(35.1 \%)$ isolates formed a biofilm moderately. The number of $P$. aeruginosa isolates intensively forming the biofilm was $21(63.6 \%)$; the remaining part formed a biofilm in a moderate degree $-14(42.4 \%)$.

When analyzing the results of determining the mass of the formed microbial biofilm, it was found out that P. mirabilis (65.9 [65.1-71.8] g/well; $\mathrm{p}<0.05)$ had the highest ability among the studied isolates compared with other microorganisms. $P$. aeruginosa isolates formed a biofilm weighing 44.7 [23.0-75.1] g / well, S. aureus - 35.4 [20.8$68.0] \mathrm{g} /$ well, K. pneumoniae -35.2 [23.7-48.2] g/ well, Acinetobacter spp. - 29.4 [20.4-44.2] g/well. The results are presented in Fig. 1.

The $K$. pneumoniae isolates were most sensitive to tigecycline, both in the planktonic form and in the composition of the biofilm $(100 \%$ of the sensitive isolates). 71 (94.7\%) isolates in both planktonic form and biofilm form turned out to be carbapenem-resistant. The results are presented in tables 4 and 5 .

Table 2

Isolates identified by the bacteriological method and confirmed by polymerase chain reaction

\begin{tabular}{lcc}
\hline \multicolumn{1}{c}{ Obtained isolates } & $\begin{array}{c}\text { The number of isolates identified by the } \\
\text { bacteriological method }(\%)\end{array}$ & $\begin{array}{c}\% \text { PCR confirmed } \\
\text { cases }\end{array}$ \\
\hline K. pneumoniae & $3(20 \%)$ & $100 \%$ \\
$*$ Acinetobacter spp. & $1(6.7 \%)$ & was not done \\
$*$ Acinetobacter spp. + K. pneumoniae & $1(6.7 \%)$ & was not done \\
$P$. aeruginosa + K. pneumoniae & $3(20 \%)$ & $100 \%$ \\
$S$. aureus $+K$. pneumoniae & $2(13.4 \%)$ & $100 \%$ \\
No isolates fourd & $3(20 \%)$ & $0 \%$ \\
\hline Note $*$ identifiction of Acinetobacter spp. by PCR was not performed becaus of the lackof reagents.
\end{tabular}

Note: * identification of Acinetobacter spp. by PCR was not performed because of the lack of reagents.

Table 3

Microbial associations identified by polymerase chain reaction

\begin{tabular}{|c|c|}
\hline Obtained isolates & Number $(\%)$ \\
\hline S. aureus + Streptococcus spp. & $1(6.7 \%)$ \\
\hline K. pneumoniae + E. coli + Streptococcus spp. & $1(6.7 \%)$ \\
\hline K. pneumoniae + Streptococcus spp. & $3(20 \%)$ \\
\hline S. aureus $+K$. pneumoniae + Streptococcus spp. $+P$. aeruginosa & $3(20 \%)$ \\
\hline S. aureus $+K$. pneumoniae + Streptococcus spp. + E. coli & $1(6.7 \%)$ \\
\hline K. pneumoniae + Proteus spp. $+P$. aeruginosa $+S$. aureus + Streptococcus spp. & $1(6.7 \%)$ \\
\hline K. pneumoniae $+E$. coli $+P$. aeruginosa $+S$. aureus + Streptococcus spp. & $1(6.7 \%)$ \\
\hline Streptococcus spp. $+S$. aureus $+K$. pneumoniae & $1(6.7 \%)$ \\
\hline Enterobacter spp. + Streptococcus spp. & $1(6.7 \%)$ \\
\hline $\begin{array}{l}\text { P.aeruginosa }+ \text { Enterobacter spp. }+ \text { Serratia spp. }+ \text { E. coli }+ \text { S. aureus }+ \text { Proteus spp. }+ \text { Streptococcus spp. }+ \\
\text { K. pneumoniae }\end{array}$ & $1(6.7 \%)$ \\
\hline
\end{tabular}




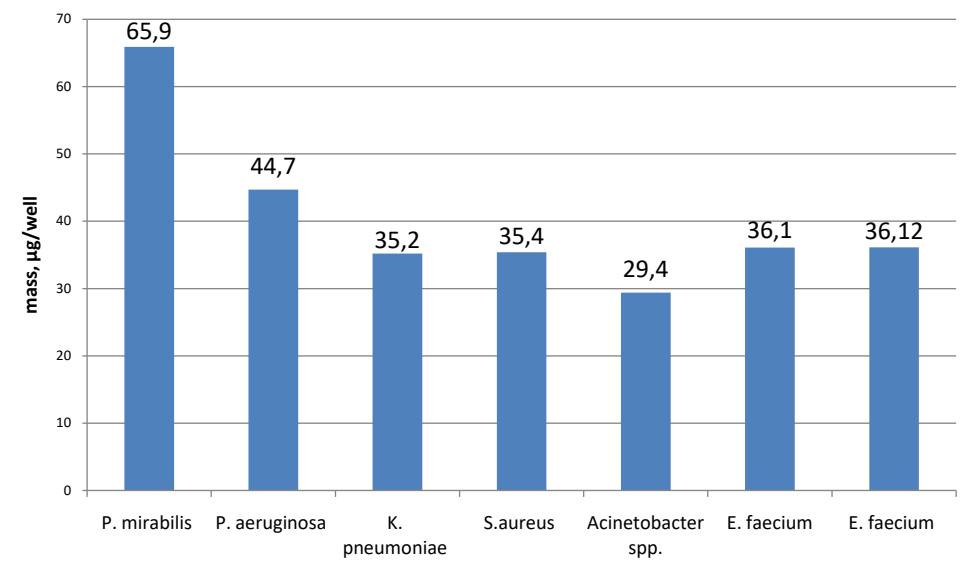

Fig. 1. The mass of microbial biofilms $\mathrm{g} /$ well.

The sensitivity of clinical isolates of $K$. pneumoniae in planktonic form

Table 4

\begin{tabular}{lcccccccc}
\hline & $\mathrm{S}, \%$ & $\mathrm{I}, \%$ & $\mathrm{R}, \%$ & $\mathrm{MIC}_{50}$ & $\mathrm{MIC}_{90}$ & Geometric mean of MIC & Min/Max & Quartiles \\
\hline Cefepime & 0 & 0 & 100 & $172.3^{*}$ & $296.8^{*}$ & 165.2 & $4 / 256$ & $256 ; 256$ \\
Ceftriaxone & 0 & 0 & 100 & $144.6^{*}$ & $242.5^{*}$ & 198.3 & $2 / 256$ & $256 ; 256$ \\
Imipenem & 5.3 & 0 & 94.7 & 269.4 & 489.1 & 99.2 & $4 / 256$ & $64 ; 256$ \\
Meropenem & 0 & 5.3 & 94.7 & 224.4 & 398.1 & 132.7 & $4 / 256$ & $128 ; 256$ \\
Ciprofloxacin & 5.3 & 0 & 94.7 & 2.9 & 5.1 & 10.7 & $0.25 / 32$ & $4 ; 32$ \\
Moxifloxacin & 0 & 0 & 100 & 1.3 & 1.7 & 21.4 & $2 / 256$ & $12 ; 32$ \\
Tigecycline & 100 & 0 & 0 & 1.4 & 1.2 & 0.8 & $0.25 / 1$ & $0.75 ; 1$ \\
\hline
\end{tabular}

Note: ${ }^{*}$ for antibiotics, the upper limit of $\mathrm{MIC}_{50}$ and $\mathrm{MIC}_{90}$ was not determined; $\mathrm{S}-$ antibiotic sensitive isolates; I - antibiotic moderately sensitive isolates; $\mathrm{R}$ - antibiotic non-sensitive isolates; $\mathrm{MIC}_{50}-$ minimum inhibitory concentration for $50 \%$ of isolates; $\mathrm{MIC}_{90}$ - minimum inhibitory concentration for $90 \%$ of isolates; Geometric mean of MIC - geometric mean overwhelming concentration; Min/Max - The minimum antibiotic concentration in $\mathrm{g} / \mathrm{ml}$ at which the isolate is sensitive to the antibiotic.

The sensitivity of clinical isolates of $K$. pneumoniae in the composition of the biofilm

Table 5

\begin{tabular}{lcccccccc}
\hline & $\mathrm{S}, \%$ & $\mathrm{I}, \%$ & $\mathrm{R}, \%$ & $\mathrm{MIC}_{50}$ & $\mathrm{MIC}_{90}$ & Geometric mean of MIC & Min/Max & Quartiles \\
\hline Cefepime & 0 & 0 & 100 & $174.8^{*}$ & $301.6^{*}$ & 177.7 & $4 / 256$ & $256 ; 256$ \\
Ceftriaxone & 0 & 0 & 100 & $144.6^{*}$ & $242.5^{*}$ & 198.3 & $2 / 256$ & $256 ; 256$ \\
Imipenem & 0 & 5.3 & 94.7 & 321.8 & 579.0 & 51.4 & $2 / 256$ & $24 ; 256$ \\
Meropenem & 0 & 5.3 & 94.7 & 87.4 & 130.3 & 103.4 & $4 / 128$ & $128 ; 128$ \\
Ciprofloxacin & 5.3 & 0 & 94.7 & 2.8 & 5.1 & 12.4 & $0.25 / 32$ & $4 ; 32$ \\
Moxifloxacin & 0 & 0 & 100 & 1.5 & 2.1 & 25.7 & $2 / 128$ & $16 ; 32$ \\
Tigecycline & 100 & 0 & 0 & 1.4 & 1.2 & 1 & $0.5 / 2$ & $1 ; 1$ \\
\hline Note: * for antibiotics,
\end{tabular}

Note: * for antibiotics, the upper limit of $\mathrm{MIC}_{50}$ and $\mathrm{MIC}_{90}$ was not determined; $\mathrm{S}-$ antibiotic sensitive isolates; I - antibiotic moderately sensitive isolates; $\mathrm{R}$ - antibiotic non-sensitive isolates; $\mathrm{MIC}_{50}-$ minimum inhibitory concentration for $50 \%$ of isolates; $\mathrm{MIC}_{90}$ - minimum inhibitory concentration for $90 \%$ of isolates; Geometric mean of MIC - geometric mean overwhelming concentration; Min/Max- The minimum antibiotic concentration in $\mathrm{g} / \mathrm{ml}$ at which the isolate is sensitive to the antibiotic.

All 75 (100\%) isolates in both forms were sensitive to tigecycline $(100 \%)$, showing resistance to carbapenems in 71 cases $(94.7 \%)$, to cephalosporins - in $75(100 \%)$ cases. For $90 \%$ of the studied IPC isolates for tigecycline and ciprofloxacin in the composition of biofilm forms does not change, but increases for moxifloxacin 1.3 times and meropenem 1.2 times, which reduces the effectiveness of antibacterial therapy.

The results are presented in Fig. 2.

$32(91.4 \%)$ of the investigated $K$. pneumoniae clinical isolates possessed one or another resistance gene. The OXA-48 gene was most frequently isolated in $20(80 \%)$ cases, $17(51.4 \%)$ of the isolates had the CTX-M gene and $1(2.86 \%)$ the NDM gene. $12(37.14 \%)$ immediately had 3 resistance genes CTX-M, OXA-48, NDM, 1 (2.86\%) - NDM and CTX-M; 12 (37.1\%) - NDM and OXA-48; 4 $(11.4 \%)-$ CTX-M and OXA-48. The results are presented in tables 6 and 7 .

A positive correlation was found out between the presence of any of the carbapenem resistance genes and the phenotypic carbapenem resistance of $K$. pneumoniae $(\mathrm{r}=0.6, \mathrm{p}<0.05)$. 


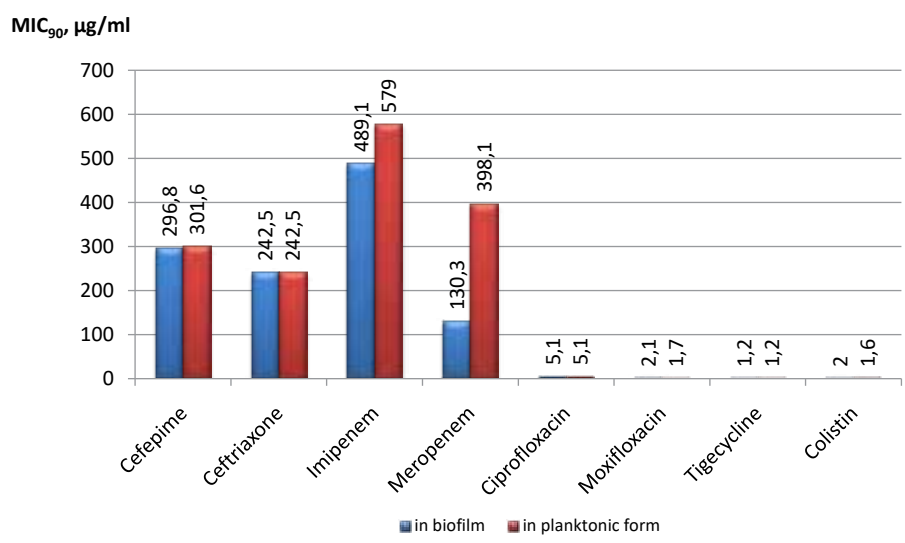

Fig. 2. The sensitivity of clinical isolates

of $K$. pneumoniae in planktonic form and in the composition of the biofilm.

Table 6

The presence of resistance genes in $K$. pneumoniae

\begin{tabular}{lccccccccc}
\hline Microorganism & Total isolates & VIM & $\%$ & NDM & $\%$ & OXA-48 & $\%$ & CTX-M & $\%$ \\
\hline K. pneumoniae & 35 & 0 & 0 & 1 & 2,9 & 28 & 80 & 18 & 51.4 \\
\hline Note: VIM, NDM, OXA-48, CTX-M - resistance genes. & & & & & &
\end{tabular}

Association of resistance genes in $K$. pneumoniae

\begin{tabular}{cccccccccc}
\hline Microorganism & $\begin{array}{c}\text { Total } \\
\text { isolates }\end{array}$ & $\begin{array}{c}\text { NDM } \\
\text { OXA-48 CTX-M }\end{array}$ & $\%$ & $\begin{array}{c}\text { NDM } \\
\text { CTX-M }\end{array}$ & $\%$ & $\begin{array}{c}\text { NDM } \\
\text { OXA-48 }\end{array}$ & $\%$ & $\begin{array}{c}\text { CTX-M } \\
\text { OXA-48 }\end{array}$ & $\%$ \\
\hline K. pneumoniae & 35 & 13 & 37.1 & 1 & 2.9 & 13 & 37.1 & 4 & 11.4 \\
\hline
\end{tabular}

Note: VIM, NDM, OXA-48, CTX-M - resistance genes.

\section{Discussion}

Enterobacteriacea and Acinetobacter spp. were most frequently observed, which corresponds to the data of domestic and foreign authors [1]. $K$. pneumoniae, being an important representative of this family, is of great importance in the structure of nosocomial pathogens. So far, starting therapy for severe infections has been carbapenems, which has led in many countries to the rapid spread of antibiotic resistance to this group of antibiotics, including in the Republic of Belarus [6]. The main cause of resistance was the production of carbapenemases that inactivate $\beta$-lactam antibiotics [14]. At present, molecular diagnostic methods are actively used, which allow determining the formation mechanisms of resistance to antibacterial drugs by the presence of resistance genes. This allows optimizing the strategy of antibiotic therapy and predicting resistance. According to the results of the study, $94.7 \%$ of the studied clinical isolates of $K$. pneumoniae were also resistant to carbapenems that have 1 or more resistance genes in their composition. Moreover, microorganisms in the composition of biofilms have higher rates of MIC, which makes it difficult for an antibiotic to penetrate the site of infection [15]. MIC of the studied antibiotics in the composition of biofilms increased for carbapenems, moxifloxacin and did not change for tigecycline and ciprofloxacin.

\section{Conclusions}

1. In the structure of identified isolates, the most frequent pathogens in the intensive care unit were the representatives of $K$. pneumonia $(33.5 \%)$ and Acinetobacter spp. (32.6\%). In $91.4 \%$ of the studied clinical isolates of K. pneumoniae, the genes responsible for antibiotic resistance to carbapenems and cephalosporins were identified, and OXA-48 was the most frequently isolated gene for resistance to carbapenems $(80 \%)$.

2. All the examined isolates formed a biofilm well or moderately. Among the studied microorganisms in representatives of $P$. mirabilis, this ability is most pronounced 65.9 [65.1-71.8] g / well.

3. Microorganisms in the composition of biofilms become more resistant to antibiotics, which leads to ineffectiveness from the prescribed antibiotic therapy.

4. PCR diagnostics is a promising method of microbiological identification, which allows geting results in 4 hours, which is extremely important for the rapid appointment of rational antibacterial therapy in the intensive care unit.

5. It had been established that for the treatment of infections, the etiological factor of which is $K$. pneumonia resistant to carbapenems, tigecyclin can be used based on the microbiological approach. 


\section{Funding}

The work was carried out in accordance with the plan of scientific works of Vitebsk State Medical University.

\section{Conflict of interest}

The authors declare that they have no conflict of interest.

\section{Ethical aspects Ethics Committee approval}

The article complied with ethical standards and the research has been approved by the Ethics Committee of Vitebsk State Medical University.

\section{ЛИТЕРАТУРА}

1. Mukhopadhyay C. Infection Control in Intensive Care Units. Indian J Respir Care. 2018;(7):14-21. doi: 10.4103/ijrc.ijrc 917

2. Ibrahim EH, Sherman $\mathrm{G}$, Ward $\mathrm{S}$, Fraser VJ, Kollef MH. The influence of inadequate antimicrobial treatment of bloodstream infections on patient outcomes in the ICU setting. Chest. 2000 Jul;118(1):146-55. doi: 10.1378/chest.118.1.146

3. Яковлев СВ, Суворова МП, Белобородов ВБ, Басин ЕЕ, Елисеева ЕВ, Ковеленов СВ, Портнягина УС, Рог АА, Руднов ВА, Барканова ОН. Распространённость и клиническое значение нозокомиальных инфекций в лечебных учреждениях России: исследование Эргини. Антибиотики и Химиотерапия. 2016;61(5-6):32-42. https://cyberleninka.ru/ article/n/rasprostranyonnost-i-klinicheskoe-znachenienozokomialnyh-infektsiy-v-lechebnyh-uchrezhdeniyahrossii-issledovanie-ergini

4. Kumar A, Ellis P, Arabi Y, Roberts D, Light B, Parrillo JE, Dodek P, Wood G, Kumar A, Simon D, Peters C, Ahsan M, Chateau D. Initiation of inappropriate antimicrobial therapy results in a fivefold reduction of survival in human septic shock. Chest. 2009 Nov;136(5):1237-48. doi: 10.1378/chest.09-0087

5. Зубков МН. Роль карбапенемов в условиях эскалации антибиотикорезистентности грамотрицательных бактерий. РМЖ. 2008;16(2): 106-12. https:// www.rmj.ru/articles/antibiotiki/Roly_karbapenemov_v usloviyah eskalacii antibiotikorezistentnosti gramotricatelynyh bakteriy/\#ixzz5idYgvUxm

6. Земко ВЮ, Окулич ВК, Дзядзько АМ. Мониторинг антибиотикорезистентности микроорганизмов в отделении реанимации и интенсивной терапии многопрофильного стационара. Трансплантология. 2018;10(4):284-97. https://doi.org/10.23873/20740506-2018-10-4-284-297

7. Лазарева ИВ, Агеевец ВА, Ершова ТА, Зуева ЛП, Гончаров АЕ, Дарьина МГ, Светличная ЮС, Усков АН, Сидоренко СВ. Распространенность и антибактериальная резистентность грамотрицательных бактерий, продуцентов карбапенемаз, в Санкт-Петербурге и некоторых других регионах Российской Федерации. Антибиотики $и \mathrm{Xu}$ миотерапия. 2016;61:11-12. https://cyberleninka. $\mathrm{ru} /$ article/v/rasprostranenie-i-antibakterialnaya- rezistentnost-gramotritsatelnyh-bakteriy-produtsentovkarbapenemaz-V-sankt-peterburge-i

8. Воробей ЕС, Воронкова ОС, Винников АИ. Бактериальные биопленки. Quorum sensing - «Чувство кворума» у бактерий в биопленках. Вісник Дніпропетровського університету. Біологія. Екологія. 2012;20 (1):13-22. https://cyberleninka.ru/article/n/ bakterialnye-bioplenki-quorum-sensing-chuvstvo-kvoruma-u-bakteriy-v-bioplenkah

9. Глушанова НА, Блинов АИ, Алексеева НБ. Бактериальные биопленки в инфекционной патологии человека. Медицина в Кузбассе. 2015:30-35. https:// cyberleninka.ru/article/n/bakterialnye-bioplenki-v-infektsionnoy-patologii-cheloveka

10. Лопухов ЛВ, Эйдельштейн МВ. Полимеразная цепная реакция в клинической микробиологической диагностике. Клин Микробиология и Антимикробная Химиотерапия. 2000;4(2):96-106. http:// www.antibiotic.ru/cmac/2000_2_3/096.htm

11. Коломиец НД, Тонко $\overline{\mathrm{B}}$, Сероокая ТИ, Марейко АМ, Литуновская ЛГ, Ермакова ГС, Колодкина ВЛ, Сергейчик НЛ, Левшина НН, Славинская АА, Точко НИ, Войтик СБ, Новомлиянова ЛВ, Шитикова ПВ, Клюйко НЛ, Куличковская ИВ. Микробиологические методы исследования биологического материала: инструкция по применению; 075-0210. Минск, РБ: Дикта; 2010; 75 с. http://gocb.by/assets/files/methodical/LS/75-0210.pdf 12. Окулич ВК, Кабанова АА, Плотников ФВ. Микробные биопленки в клинической микробиологии и антибактериальной терапии: моногр. Витебск, РБ; 2017. 300 c. http://elib.vsmu.by/handle $/ 123 / 12846$

13. The European Committee on Antimicrobial Susceptibility Testing. Breakpoint tables for interpretation of MICs and zone diameters. Version 8.1, 2018. http://www.eucast.org

14. Hamprecht A, Gottig S. Treatment of infections caused by carbapenem-resistant Enterobacteriaceae. Curr Treat Options Infect Dis. 2014;6(4):425-38. doi: 10.1007/s40506-014-0029-X

15. Saini R, Saini S, Sharma S. Biofilm: A dental microbial infection/ J Nat Sci Biol Med. 2011 JanJun;2(1):71-75. doi: 10.4103/0976-9668.82317

\section{REFERENCES}

1. Mukhopadhyay C. Infection Control in Intensive Care Units. Indian J Respir Care. 2018;(7):14-21. doi: 10.4103 /ijrc.ijrc 917

2. Ibrahim EH, Sherman G, Ward S, Fraser VJ, Kollef MH. The influence of inadequate antimicrobial treatment of bloodstream infections on patient outcomes in the ICU setting. Chest. $2000 \mathrm{Jul} ; 118(1): 146-55$. doi: 10.1378/chest.118.1.146

3. Yakovlev SV, Suvorova MP, Beloborodov VB, Basin EE, Eliseev EV, Kovelenov SV, Porthyagina US, Rog AA, Rudnov VA, Barkanova ON. Multicentre study of the prevalence and clinical value of hospital-acquired infections in emergency hospitals of Russia: ergini study. Antibiotiki $i$ Khimioterapiia. 2016;61(5-6):32-42. https://cyberleninka.ru/article/n/ rasprostranyonnost-i-klinicheskoe-znachenie-nozokomialnyh-infektsiy-v-lechebnyh-uchrezhdeniyah-rossiiissledovanie-ergini (in Russ.)

4. Kumar A, Ellis P, Arabi Y, Roberts D, Light B, Parrillo JE, Dodek P, Wood G, Kumar A, Simon D, Peters C, Ahsan M, Chateau D. Initiation of inap- 
propriate antimicrobial therapy results in a fivefold reduction of survival in human septic shock. Chest. 2009 Nov;136(5):1237-48. doi: 10.1378/chest.09-0087

5. Zubkov MN. Rol' karbapenemov v usloviiakh eskalatsii antibiotikorezistentnosti gramotritsatel'nykh bakterii. RMZh. 2008;16(2): 106-12. https://www.rmj. ru/articles/antibiotiki/Roly_karbapenemov_v_usloviyah_eskalacii_antibiotikorezistentnosti_gramotricatelynyh_bakteriy/\#ixzz5idYgvUxm (in Russ.)

6. Zemko VYu, Okulich VK, Dzvadz'kcr AM. Monitoring the antibiotic resistance in the intensive care unit of a multidisciplinary hospital. Transplantologiia. 2018;10(4):284-97. https://doi.org/10.23873/20740506-2018-10-4-284-297 (in Russ.)

7. Lazareva IV. Ageevets VA, Ershova TA, Zueva LP, Goncharov AE, Darina MG, Svetlichnaya YuS, Uskov AN, Sidorenko SV. Prevalence and antibiotic resistance of carbapenemase-producing gram-negative bacteria in Saint- Petersburg and some other regions of the Russian Federation. Antibiotiki $i$ Khimioterapiia. 2016;61:11-12. https://cyberleninka.ru/article/v/ rasprostranenie-i-antibakterialnaya-rezistentnostgramotritsatelnyh-bakteriy-produtsentov-karbapenemaz-v-sankt-peterburge-i (in Russ.)

8. Vorobey ES, Voronkova OS, Vinnikov AI. Bacterial biofllms. "Bacteria quorum" sensing in biofilms. Visnik Dnipropetrovs'kogo universitetu. Biologiia. Ekologiia. 2012;20 (1):13-22. https://cyberleninka.ru/ article/n/bakterialnye-bioplenki-quorum-sensing-chuvstvo-kvoruma-u-bakteriy-v-bioplenkah (in Ukr.) 9. Glushanova NA, Blinov AI, Alekseeva NB. Bacterial biofilms in human infectious pathology. Medit-

\section{Адрес для корреспонденции}

210009, Республика Беларусь,

г. Витебск, пр-т Фрунзе 27a,

Витебский государственный

медицинский университет,

кафедра анестезиологии

и реаниматологии с курсом ФПК и ПК,

тел. моб. +375291460799,

e-mail: torinet@tut.by,

Земко Виктория Юрьевна

\section{Сведения об авторах}

Земко Виктория Юрьевна, аспирант кафедры анестезиологии и реаниматологии с курсом ФПК и ПК, Витебский государственный медицинский университет, г. Витебск, Республика Беларусь. https://orcid.org/0000-0002-6753-2074

Окулич Виталий Константинович, к.м.н., доцент кафедры клинической микробиологии, Витебский государственный медицинский университет, г. Витебск, Республика Беларусь.

https://orcid.org/0000-0002-8226-6405

Дзядзько Александр Михайлович Дзядзько, д.м.н., заведующий отделом анестезиологии и реанимации, Минский научно-практический центр хирургии, трансплантологии и гематологии, г. Минск, Республика Беларусь.

https://orcid.org/0000-0003-1965-1850

\section{Информация о статье}

Поступила 3 августа 2018 г.

Принята к публикации 25 марта 2019 г.

Доступна на сайте 30 апреля 2019 г. sina v Kuzbasse. 2015:30-35. https://cyberleninka.ru/ article/n/bakterialnye-bioplenki-v-infektsionnoy-patologii-cheloveka (in Russ.)

10. Lopukhov LV, Edelstein MV. Polymerase chain reaction in diagnostic clinical microbiology. Klin Mikrobiologiia i Antimikrobnaia Khimioterapiia. 2000;4(2):96106. http://www.antibiotic.ru/cmac/2000_2_3/096.htm (in Russ.)

11. Kolomiets ND, Tonko OV, Serookaia TI, Mareiko AM, Litunovskaia LG, Ermakova GS, Kolodkina VL, Sergeichik NL, Levshina NN, Slavinskaia AA, Tochko NI, Voitik SB, Novomliianova LV, Shitikova PV, Kliuiko NL, Kulichkovskaia IV. Mikrobiologicheskie metody issledovaniia biologicheskogo materiala: instruktsiia po primeneniiu; 075-0210. Minsk, RB: Dikta; 2010; 75 p. http://gocb.by/assets/files/methodical/LS/75-0210.pdf (in Russ.)

12. Okulich VK, Kabanova AA, Plotnikov FV. Mikrobnye bioplenki v klinicheskoi mikrobiologii i antibakterial'noi terapii: monogr. Vitebsk, RB; 2017. 300 p. http://elib.vsmu.by/handle/123/12846 (in Russ.) 13. The European Committee on Antimicrobial Susceptibility Testing. Breakpoint tables for interpretation of MICs and zone diameters. Version 8.1, 2018. http://www.eucast.org

14. Hamprecht A, Gottig S. Treatment of infections caused by carbapenem-resistant Enterobacteriaceae. Curr Treat Options Infect Dis. 2014;6(4):425-38. doi: 10.1007/s40506-014-0029-x

15. Saini R, Saini S, Sharma S. Biofilm: A dental microbial infection. J Nat Sci Biol Med. 2011 JanJun;2(1):71-75. doi: 10.4103/0976-9668.82317

\section{Address for correspondence}

210009, The Republic of Belarus,

Vitebsk, Frunze Avenue, 27a,

Vitebsk State Medical University,

Department of Anesthesiology and Resuscitation

With a Course of the Faculty of the Advanced

Training and Retraining of Specialists,

Tel. mobile +375291460799 ,

e-mail: torinet@tut.by,

Viktoryia Yu. Ziamko

\section{Information about the authors}

Ziamko Viktoryia Yu., Post-Graduate Student of the Department of Anesthesiology and Resuscitation with a Course of the Faculty of the Advanced Training and Retraining of Specialists, Vitebsk State Medical University, Vitebsk, Republic of Belarus.

https://orcid.org/0000-0002-6753-2074

Okulich Vitaly K., PhD, Associate Professor of the Clinical Microbiology Department, Vitebsk State Medical University, Vitebsk, Republic of Belarus. https://orcid.org/0000-0002-8226-6405

Dzyadzko Alexander M., MD, Head of the Intensive Care Unit, Minsk Scientific and Practical Center of Surgery, Transplantation and Hematology, Minsk, Republic of Belarus.

https://orcid.org/0000-0003-1965-1850

\section{Article history}

Arrived 03 August 2018

Accepted for publication 25 March 2019

Available online 30 April 2019 